사료 중 단백질 수준 및 CLA (Conjugated Linoleic Acid) 첨가가

\author{
비육돈의 생산성 및 육질특성에 미치는 영향 \\ 문홍길 · 이성대 · 정현정 · 김영화 · 박준철 · 지상윤 · 김종대 · 권오섭 · 김인철 \\ 농촌진흥청 축산과학원 양돈과
}

\title{
Effects of Dietary Protein Level and Supplementation of Conjugated Linoleic Acid on Growth Performance and Meat Quality Parameters in Finishing Pigs
}

Hong Kil Moon, Sung Dae Lee, Hyun Jung Jung, Young Hwa Kim, Jun Cheol Park, Sang Yun Ji, Chong Dae Kim, Oh Sub Kwon and In Cheul Kim

Swine Science Division, National Institute of Animal Science, RDA, Cheonan 330-801, Korea

\begin{abstract}
This study was conducted to investigate effects of dietary crude protein (CP) level and supplementation of conjugated linoleic acid (CLA) on growth performances and meat quality parameters in finishing pigs. The experiment was designed using protein levels $(11.3 \%, 16.0 \%)$ and CLA levels $(0 \%, 2.5 \%)$ according to $2 \times 2$ factorial design. A total of forty-eight pigs [(Landrace $\times$ Yorkshire $) \times$ Duroc] with an average initial weight of $79 \pm 1 \mathrm{~kg}$ were allotted to one of four dietary treatments. Each treatment had four replications of three pigs per replicate. Final body weight $(\mathrm{P}<0.05)$ and average daily gain $(\mathrm{P}<0.01)$ were lower in $11.3 \%$ CP treatments than in $16.0 \%$ CP treatments, while feed/gain was high $(\mathrm{P}<0.01)$ in $11.3 \%$ CP treatments compared with $16.0 \% \mathrm{CP}$ treatments. Carcass weight was lighter in $11.3 \% \mathrm{CP}$ treatments $(\mathrm{P}<0.001)$ and CLA $2.5 \%$ treatments $(\mathrm{P}<0.01)$ than in $16.0 \%$ CP and CLA $0 \%$ treatments, respectively. A significant interaction between CP and CLA on carcass weight was observed $(\mathrm{P}<0.01)$, where supplementation of $2.5 \%$ CLA to finishing diets decreased carcass weight in $16.0 \%$ CP treatments, while no difference was found in $11.3 \%$ CP treatments. Backfat thickness was thinner in $11.3 \%$ CP treatments and CLA $2.5 \%$ treatments than in $16.0 \%$ CP and CLA $0 \%$ treatments, respectively $(\mathrm{P}<0.05)$. A significant interaction between CP and CLA on backfat thickness was observed $(\mathrm{P}<0.001)$, where supplementation of $2.5 \%$ CLA to finishing diets decreased backfat thickness in $16.0 \%$ CP treatments, while no difference was found in $11.3 \% \mathrm{CP}$ treatments. Marbling score and intramuscular fat contents were higher in $11.3 \% \mathrm{CP}$ treatments than in $16.0 \%$ CP treatments $(\mathrm{P}<0.01)$. In conclusion, feeding of protein-deficient diets in finishing pigs could produce favorable pork with high marbling score and thinner backfat. On the other hand, supplementation of CLA was considered to decrease backfat thickness when diets with optimal level of crude protein were fed to finishing pigs.
\end{abstract}

(Key words : Pig, Crude protein, CLA, Growth performance, Marbling score, Intramuscular fat)

Corresponding author : S. D. Lee, Swine Science Division, National Institute of Animal Science, RDA, Cheonan 330-801, Korea. Tel.: +82-41-580-3452, Fax.: +82-41-580-3459, E-mail : leesd07@rda.go.kr 


\section{I. 서 론}

최근 건강에 대한 관심 고조로 소비자들이 지방을 기피함에 따라 돈육산업에 있어서도 저 지방 돈육을 생산하기 위한 육종 및 영양학적 시도가 이루어지고 있다. 그러나 다른 한편으 로는 종돈이 살코기형 (lean type)으로 개량됨에 따라 돈육의 근내지방 (intramuscular fat) 함량이 줄어 다즙성 및 연도가 떨어짐으로써 (Hodgson 등, 1991; Castell 등, 1994) 돼지고기의 기호성 에 부정적인 영향을 미칠 수 있다.

Conjugated linoleic acid(CLA)는 필수지방산 인 linoleic acid의 이성체로서 주로 9 번과 11 번 또는 10 번과 12 번 탄소에 cis- 및 trans-형 이 중결합을 가지고 있으며, 항암, 항산화, 항비만 등의 다양한 효과가 보고된 바 있다 $(\mathrm{Ha}$ 등, 1998; Fitch, 1996; Pariza 등, 2000; Brown and Mclntosh, 2003). 지방대사와 관련하여 CLA는 혈액으로부터 triglycerides를 지방세포로 전이시 켜 축적시키는데에 관여하는 효소인 lipoprotein lipase (LPL)의 활력은 저하시키고, 지방세포에 서 지방의 분해 (lipolysis) 및 지방세포의 사멸 (adipocyte apoptosis)은 촉진시키는 반면, 에너지 생산을 위하여 지방산을 미토콘드리아로 수송 시키는데 관여하는 효소인 carnitine palmitoyltransferase (CPT)의 활력은 증가시켜, 결론적 으로 체지방 함량을 감소시킨다고 보고된 바 있다 (Park 등, 1997; Evans 등, 2000).

한편 돼지고기의 근내지방 함량은 종돈의 육 질형질에 의해 크게 좌우되지만, 여러 연구자 들에 의해 저 단백질 또는 저 lysine 사료 급여 시 근내지방 함량이 증가한다고 보고되었다 (Castell 등, 1994; Essen-Gustavsson 등, 1994; Kerr 등, 1995; Cisneros 등, 1996; Blanchard 등, 1999; Witte 등, 2000; Donato 등, 2006; Park 등, 2006). 돼지의 경우 흡수된 lysine 및 methionine 을 이용하여 간과 신장에서 carnitine을 합성하 며 근육에 주로 축적한다 (Mayes 등, 1996). 근 육에 존재하고 있는 carnitine은 지방산의 분해 를 촉진하는 데, 저 단백질 또는 저 lysine 사료 급여로 낮아진 carnitine 함량은 지방산 분해를 저하시킴으로써 근육내 지방축적을 증가 시킬
수 있다 (Heo 등, 2000). 또한 저 단백질이나 저 lysine 사료 급여 시 근육단백질 합성효율의 저 하로 인한 여분의 아미노산이 분해되어 체지방 합성에 이용된다 (Witte 등, 2000).

따라서 본 연구는 사료 내 조단백질 및 CLA 수준과 그들간의 상호작용이 비육돈의 성장 및 육질특성에 미치는 효과를 구명하기 위하여 수 행하였다.

\section{ㅍ. 재료 및 방법}

\section{1. 사양시험}

(1) 공시동물 및 시험사료

공시동물은 일령이 비슷하고 체중 $79 \pm 1 \mathrm{~kg}$ 의 3 원교잡종 거세돈 48 두를 공시하였다. 처리 구는 사료 중 조단백질 함량 2 수준 $(11.3 \%$, $16.0 \%)$ 과 CLA 첨가 2 수준 $(0 \%, 2.5 \%)$ 의 $2 \times 2$ 요인실험으로, 처리 당 4 반복, 반복 당 3 두씩 완전임의배치하였다. 시험사료의 원료구성 및 성분조성은 Table 1에 나타나 있다. 시험에 이 용한 CLA는 Ha 등(1990)의 방법으로 홍화유를 이용하여 합성하였으며, 최종 회수한 CLA의 순도는 50\%로 주요 이성체는 cis-9, trans- 11 octadecadienoic acid isomer이다. 시험사료에서 기타 영양소 수준은 NRC (1998) 권장량 이상으 로 제조하였다. 시험사료는 무제한 급여하였으 며, 음수는 니플을 이용하여 자유급수 하였다. 시험돈사는 무창 돈사로 돈방 면적은 $320 \times 150$ $\mathrm{cm}$ 이었다. 기타 사양관리는 일반적인 관행에 준하여 실시하였다.

\section{(2) 조사항목 및 분석방법}

개시체중 및 종료체중을 측정한 후, 총 증체 량을 사육일수로 나누어 일당증체량을 계산하 였다. 일당 사료섭취량은 총 사료섭취량을 사육 일수로 나누어 계산하였고, 사료요구율은 총 사 료섭취량을 총 증체량으로 나누어 계산하였다.

\section{2. 도체 분석}

공시동물 48 두는 사양시험 종료 후 도축장에 
Table 1. Ingredients and chemical composition of the experimental diets (\%, as fed basis)

\begin{tabular}{lccccc}
\hline Crude protein in diets, \% & \multicolumn{2}{c}{11.3} & & \multicolumn{2}{c}{16.0} \\
\cline { 2 - 3 } \cline { 5 - 6 } CLA in diets, \% & 0 & 2.5 & 0 & 2.5 \\
\hline Ingredients, \% & & & & \\
$\quad$ Corn & 73.51 & 73.51 & & 60.70 & 60.70 \\
$\quad$ Soybean meal & 9.00 & 9.00 & & 22.00 & 22.00 \\
Wheat & 10.10 & 10.10 & & 10.10 & 10.10 \\
Tallow & 5.00 & - & & 5.00 & - \\
CLA (50\%) & - & 5.00 & & - & 5.00 \\
Limestone & 0.58 & 0.58 & & 0.65 & 0.65 \\
Calcium phosphate & 1.11 & 1.11 & & 0.85 & 0.85 \\
Salt & 0.30 & 0.30 & & 0.30 & 0.30 \\
Vit.+Min. Mix. ${ }^{1)}$ & 0.40 & 0.40 & & 0.40 & 0.40 \\
\hline Chemical composition ${ }^{2)}$ & & & & \\
DE, kcal/kg & 3,642 & 3,680 & 3,644 & 3,682 \\
CP, \% & 11.30 & 11.30 & & 16.00 & 16.00 \\
Lysine, \% & 0.45 & 0.45 & 0.77 & 0.77 \\
Ca, \% & 0.55 & 0.55 & 0.55 & 0.55 \\
P, \% & 0.50 & 0.50 & 0.50 & 0.50 \\
\hline
\end{tabular}

1) Vit. -min. mixture contains as followings in $1 \mathrm{~kg}$ : Vitamin A 5,000,000 IU, Vitamin $D_{3}$ 1,000,000 IU, Vitamin E $1,000 \mathrm{mg}$, Vitamin $\mathrm{B}_{1} 150 \mathrm{mg}$, Vitamin $\mathrm{B}_{2} 300 \mathrm{mg}$, Vitamin $\mathrm{B}_{12}$ 1,500 mg, Niacin amide 1,500 mg, DLcalcium phatothenate 1,000 mg, Folic acid $200 \mathrm{mg}$, Vitamin H $10 \mathrm{mg}$, Choline chloride 2,000 mg, Mn 3,800 mg, Zn 1,500 mg, Fe 4,000 mg, Cu 500 mg, I 250 mg, Co 100 mg, Mg 200 mg.

2) Calculated value

서 12 시간 절식한 후 도축하였으며, 도체는 냉 각실 $\left(2 \pm 2^{\circ} \mathrm{C}\right)$ 에서 24 시간 냉각하였다. 도체중량, 도체율 그리고 도체 길이는 $\mathrm{Kim}$ 등 (2002)의 방법으로 계산하였다. 등지방 두께는 마지막 등뼈와 제 1 허리뼈 사이 및 제 11 등뼈와 제 12 등뼈 사이의 등지방을 측정한 값의 평균치로 계산하였다. 근내지방도는 농림부고시 제 200410 호의 축산물등급판정세부기준 (1-5등급)에 따 라 등급판정사가 판정하였다.

\section{3. 육질 분석}

도축 후 24시간 예냉한 도체에서 배최장근 (Longissimus dorsi muscle)을 정형한 후 채취한
시료를 육질분석을 위한 공시재료로 이용하였 다. $\mathrm{pH}$ 는 도축 24 시간 후 좌도체 등심 제 10 늑 골부위에서 $\mathrm{pH}$ meter (NWKbinar $\mathrm{pH}$ K-21, Germany)를 이용하여 측정하였다. 조지방은 $\mathrm{AOAC}$ (1995) 방법에 준하여 분석하였다. 육색 은 등심근 단면을 자른 후 $4{ }^{\circ} \mathrm{C}$ 에서 30 분간 발 색시킨 후 색차계(CR-300, Minolta, Japan)를 이 용하여 동일한 시료를 3회 반복하여 측정하였 다. 색차계는 표준색판 No. 12633117을 이용하 여 $\mathrm{Y}=93.5, \mathrm{x}=0.3136, \mathrm{y}=0.3198$ 값으로 표준 화시켰다. 가열감량은 시료를 $2 \mathrm{~cm}$ 두께로 일정 하게 절단하여 무게를 측정하고, $70^{\circ} \mathrm{C}$ 항온수 조에서 10 분간 가열한 다음 냉각시켜 감량된 무게를 백분율로 산출하였다. 전단력은 고기시 
료 $(4 \mathrm{~cm} \times 3 \mathrm{~cm} \times 2.5 \mathrm{~cm})$ 를 $80^{\circ} \mathrm{C}$ 항온수조에서 시료 내부 중심온도가 $70^{\circ} \mathrm{C}$ 가 될 때까지 가열 한 다음 냉각시켜 직경 $0.5 \mathrm{inch}^{2}$ 의 core로 시료 를 근섬유 방향으로 채취한 후, Load cell (50 $\mathrm{kg})$, Cross-head speed $(200 \mathrm{~mm} / \mathrm{min})$ 의 조건으로 전단력 측정기 (Instron Universal Testing Machine, Model 4465, UK)를 이용하여 측정하였다. 보수 력은 마쇄한 시료 $10 \mathrm{~g}$ 을 $70^{\circ} \mathrm{C}$ 의 항온수조에서 30 분간 가열한 다음 방냉하여 $1,000 \mathrm{rpm}$ 에서 10 분간 원심분리한 후, 유리수분 함량을 측정하 고, 동일한 시료 $10 \mathrm{~g}$ 을 dish에 담아서 $102 \pm$ $1^{\circ} \mathrm{C}$ 건조기에서 항량이 될 때까지 건조시켜 전 수분 함량을 측정하여 계산하였다. 관능검사 결과는 Park 등 (1999)의 분석 방법에 준하여 잘 훈련된 관능검사 요원 15 명 중 10 명을 무작 위로 추출하여, 다즙성, 연도 및 향미에 대한 기호도를 순위법(6점 만점; 1점-매우 나쁨, 6 점-매우 좋음)으로 표시하였다.

\section{4. 통계 분석}

이상의 연구에서 얻어진 결과는 SAS (1998) 의 GLM(General Linear Model) 방법으로 분석 하였다. 처리간의 평균은 Duncan의 Multiple Range Test를 이용하여 비교하였고, 사료 중 조
단백질 및 CLA 수준의 주 효과 및 상호작용 검증을 위해 요인분석을 실시하였다. 등지방두 께 및 근내지방도는 도체중량을 공변량으로 공 분산 분석을 실시하였다.

$$
\text { III. 결 과 }
$$

사료 중 조단백질 수준과 CLA 첨가가 비육 돈의 성장 및 사료요구율에 미치는 효과는 Table 2에 나타나 있다. 종료체중 $(\mathrm{P}<0.05)$ 과 일 당증체량 $(\mathrm{P}<0.01)$ 은 조단백질 $11.3 \%$ 수준의 사 료를 섭취한 시험구가 조단백질 $16.0 \%$ 수준의 사료를 섭취한 시험구보다 유의적으로 낮았지 만, CLA 수준 및 조단백질 $\times \mathrm{CLA}$ 의 상호작용 에서는 유의성이 나타나지 않았다 $(\mathrm{P}>0.05)$. 사 료요구율 (feed/gain)은 조단백질 $11.3 \%$ 수준의 사료를 섭취한 시험구가 조단백질 $16.0 \%$ 수준 의 사료를 섭취한 시험구보다 유의적으로 높았 지만 $(\mathrm{P}<0.01), \mathrm{CLA}$ 수준 및 조단백질 $\times \mathrm{CLA}$ 의 상호작용에서는 유의성이 나타나지 않았다 ( $\mathrm{P}>0.05)$.

비육돈 사료의 조단백질과 CLA 수준에 따른 도체특성을 분석한 결과는 Table 3에 나타나 있다. 도체중량은 조단백질 $11.3 \%$ 수준의 사료 를 섭취한 시험구가 조단백질 $16.0 \%$ 수준을 섭

Table 2. Effects of dietary crude protein and CLA level on growth performance in finishing pigs

\begin{tabular}{|c|c|c|c|c|c|c|c|}
\hline \multirow{2}{*}{$\begin{array}{l}\text { Crude protein in diets, \% } \\
\text { CLA in diets, } \%\end{array}$} & \multicolumn{2}{|c|}{11.3} & \multicolumn{2}{|c|}{16.0} & \multicolumn{3}{|c|}{ Probability (P) ${ }^{1)}$} \\
\hline & 0 & 2.5 & 0 & 2.5 & $\mathrm{CP}$ & CLA & CP*CLA \\
\hline Initial body weight, kg & 78.9 & 78.4 & 78.6 & 78.7 & NS & NS & NS \\
\hline Final body weight, kg & $118.8^{\mathrm{ab}}$ & $115.5^{\mathrm{b}}$ & $128.9^{\mathrm{a}}$ & $123.8^{\mathrm{ab}}$ & $*$ & NS & NS \\
\hline ADG, kg/day & $0.739^{\mathrm{b}}$ & $0.687^{\mathrm{b}}$ & $0.932^{\mathrm{a}}$ & $0.836^{\mathrm{ab}}$ & $* *$ & NS & NS \\
\hline ADFI, kg/day & 2.86 & 2.67 & 2.86 & 2.80 & NS & NS & NS \\
\hline Feed/Gain & $3.88^{\mathrm{a}}$ & $3.89^{\mathrm{a}}$ & $3.12^{\mathrm{b}}$ & $3.36^{\mathrm{b}}$ & $* *$ & NS & NS \\
\hline Feed cost/Gain, won ${ }^{2)}$ & 896.3 & 1,019.2 & 783.1 & 947.5 & NS & NS & NS \\
\hline
\end{tabular}

1) NS, $\mathrm{P}>0.05 ; *, \mathrm{P}<0.05 ; * *, \mathrm{P}<0.01$

2) Feed cost (won $/ \mathrm{kg})$ : CP 11.3\%+CLA 0\%, 231won; CP 11.3\%+CLA 2.5\%, 262won; CP 16.0\%+CLA 0\%, 251won; CP 16.0\%+CLA 2.5\%, 282 won; Cost of CLA was assumed to be 1,078won per kg

a,b Means in the same row with different superscripts differ $(p<0.05)$ 
Table 3. Effects of dietary crude protein and CLA level on carcass characteristics

\begin{tabular}{|c|c|c|c|c|c|c|c|}
\hline \multirow{2}{*}{$\begin{array}{l}\text { Crude protein in diets, \% } \\
\text { CLA in diets, \% }\end{array}$} & \multicolumn{2}{|c|}{11.3} & \multicolumn{2}{|c|}{16.0} & \multicolumn{3}{|c|}{ Probability $(\mathrm{P})^{1)}$} \\
\hline & 0 & 2.5 & 0 & 2.5 & $\mathrm{CP}$ & CLA & $\mathrm{CP} * \mathrm{CLA}$ \\
\hline Carcass weight, kg & $90.8^{\mathrm{bc}}$ & $90.0^{c}$ & $101.1^{\mathrm{a}}$ & $93.8^{\mathrm{b}}$ & $* * *$ & $* *$ & $* *$ \\
\hline Dressing percentage, \% & 74.3 & 73.7 & 74.3 & 74.4 & NS & NS & NS \\
\hline Carcass length, cm & 105.8 & 103.3 & 106.2 & 104.8 & NS & NS & NS \\
\hline Backfat thickness, mm²) & $25.5^{\mathrm{b}}$ & $27.1^{\mathrm{b}}$ & $33.3^{\mathrm{a}}$ & $25.2^{\mathrm{b}}$ & $*$ & $*$ & $* * *$ \\
\hline Marbling score ${ }^{2)}$ & $2.13^{\mathrm{ab}}$ & $2.29^{\mathrm{a}}$ & $1.42^{\mathrm{b}}$ & $1.33^{\mathrm{b}}$ & $* *$ & NS & NS \\
\hline
\end{tabular}

1) $\mathrm{NS}, \mathrm{P}>0.05 ; *, \mathrm{P}<0.05 ; * *, \mathrm{P}<0.01, * * *, \mathrm{P}<0.001$

2) Carcass weight was used as a covariate

a,b,c Means in the same row with different superscripts differ $(\mathrm{p}<0.05)$.

Table 4. Effects of dietary crude protein and CLA level on meat quality

\begin{tabular}{|c|c|c|c|c|c|c|c|}
\hline \multirow{2}{*}{$\begin{array}{l}\text { Crude protein in diets, \% } \\
\text { CLA in diets, \% }\end{array}$} & \multicolumn{2}{|c|}{11.3} & \multicolumn{2}{|c|}{16.0} & \multicolumn{3}{|c|}{ Probability $(\mathrm{P})^{1)}$} \\
\hline & 0 & 2.5 & 0 & 2.5 & $\mathrm{CP}$ & CLA & $\mathrm{CP} * \mathrm{CLA}$ \\
\hline Intramuscular fat , \% & $2.48^{\mathrm{a}}$ & $2.57^{\mathrm{a}}$ & $1.33^{\mathrm{ab}}$ & $1.20^{\mathrm{b}}$ & $* *$ & NS & NS \\
\hline \multicolumn{8}{|l|}{ Meat color } \\
\hline CIE L* & 53.0 & 53.3 & 51.2 & 50.7 & $*$ & NS & NS \\
\hline CIE a* & 7.2 & 8.2 & 7.5 & 8.1 & NS & NS & NS \\
\hline CIE b* & 3.3 & 3.6 & 2.7 & 3.0 & NS & NS & NS \\
\hline $\mathrm{pH}$ & 5.7 & 5.5 & 5.6 & 5.6 & NS & NS & NS \\
\hline Shear force, $\mathrm{kg} / 2.5 \mathrm{inch}$ & 3.1 & 2.9 & 3.6 & 3.5 & NS & NS & NS \\
\hline WHC, \% & 51.6 & 52.8 & 53.3 & 52.5 & NS & NS & NS \\
\hline Cooking loss, \% & 31.8 & 31.2 & 29.3 & 30.8 & NS & NS & NS \\
\hline \multicolumn{8}{|l|}{ Panel test } \\
\hline Juiciness & 4.0 & 4.1 & 4.5 & 3.8 & NS & NS & NS \\
\hline Tenderness & $4.9^{\mathrm{ab}}$ & $5.1^{\mathrm{a}}$ & $4.3^{\mathrm{b}}$ & $5.1^{\mathrm{a}}$ & NS & NS & NS \\
\hline Flavor & 4.6 & 4.8 & 4.8 & 4.5 & NS & NS & NS \\
\hline
\end{tabular}

1) $\mathrm{NS}, \mathrm{P}>0.05 ; *, \mathrm{P}<0.05 ; * *, \mathrm{P}<0.01$

a,b Means in the same row with different superscripts differ $(\mathrm{p}<0.05)$.

취한 시험구보다 유의적으로 낮았으며 $(\mathrm{P}<\quad$ 적으로 감소하여, 조단백질과 CLA간 상호작용 $0.001)$, CLA $2.5 \%$ 첨가구가 CLA 무첨가구에 이 나타났다 $(\mathrm{P}<0.01)$. 그러나 도체율 및 도체길 비해 유의적으로 낮았다 $(\mathrm{P}<0.01)$. 조단백질 이는 조단백질과 CLA 수준에 따른 영향을 받 $11.3 \%$ 첨가구에서는 $\mathrm{CLA}$ 의 첨가가 도체중량에 지 않았다 $(\mathrm{P}>0.05)$. 등지방두께는 조단백질 영향을 미치지 않았으나, 조단백질 $16.0 \%$ 첨가 $\quad 11.3 \%$ 수준의 사료를 섭취한 시험구가 조단백 구에서는 CLA $2.5 \%$ 첨가 시 도체중량이 유의 질 $16.0 \%$ 수준의 사료를 섭취한 시험구보다 유 
의적으로 낮았으며 $(\mathrm{P}<0.05)$, CLA $2.5 \%$ 첨가구 가 CLA 무첨가구에 비해 유의적으로 낮았다 $(\mathrm{P}<0.05)$. 조단백질 $11.3 \%$ 첨가구에서는 $\mathrm{CLA}$ 의 첨가가 등지방두께에 영향을 미치지 않았으나, 조단백질 $16.0 \%$ 첨가구에서는 CLA $2.5 \%$ 첨가 시 등지방두께가 유의적으로 감소하여, 조단백 질과 CLA간 상호작용이 나타났다 $(\mathrm{P}<0.001)$. 반 대로 상강도(marbling score)는 조단백질 $11.3 \%$ 수준의 사료를 섭취한 시험구가 조단백질 $16.0 \%$ 수준의 사료를 섭취한 시험구보다 유의 적으로 높았으나 $(\mathrm{P}<0.01)$, CLA 첨가유무 및 조 단백질과 CLA간 상호작용에 있어서는 유의성 이 나타나지 않았다 $(\mathrm{P}>0.05)$.

비육돈 사료의 조단백질과 CLA 수준에 따른 육질특성은 Table 4에 나타내었다. 근내지방함 량은 조단백질 $11.3 \%$ 수준의 사료를 섭취한 시 험구가 조단백질 $16.0 \%$ 수준의 사료를 섭취한 시험구보다 유의적으로 높았지만 $(\mathrm{P}<0.01)$, CLA 와 조단백질 $\times \mathrm{CLA}$ 의 상호작용에서는 유의성이 나타나지 않았다. 육색에서 명도를 나타내는 $\mathrm{CIE} \mathrm{L*}$ 은 조단백질 $11.3 \%$ 수준의 사료를 섭취 한 시험구가 조단백질 $16.0 \%$ 수준의 사료를 섭 취한 시험구보다 유의적으로 높았지만 $(\mathrm{P}<0.01)$, $\mathrm{CLA}$ 와 조단백질 $\times \mathrm{CLA}$ 의 상호작용에서는 유의 성이 나타나지 않았다 $(\mathrm{P}>0.05)$. 적색도를 나타 내는 $\mathrm{CIE} \mathrm{a}^{*}$, 황색도를 나타내는 $\mathrm{CIE} \mathrm{b}^{*}, \mathrm{pH}$, 전단력, 보수력, 가열감량 그리고 관능검사에서 는 조단백질 수준, CLA 수준 그리고 조단백질 $\times \mathrm{CLA}$ 의 상호작용에서 유의성이 나타나지 않 았다 $(\mathrm{P}>0.05)$.

\section{IV. 고 찰}

비육돈에 조단백질 $11.3 \%$ 수준의 사료를 급 여 시 $16.0 \%$ 수준의 사료를 급여한 시험구에 비해 사료섭취량에서는 차이가 나지 않았으나, 종료체중 $(\mathrm{P}<0.05)$ 과 일당증체량 $(\mathrm{P}<0.01)$ 은 유의 적으로 감소하고, 사료요구율 (feed/gain)은 유의 적으로 높았다 $(\mathrm{P}<0.01)$. Loughmiller 등 (1998)은 비육기 사료에 조단백질 및 lysine 수준을 $14.74 \%-0.70 \%$ 에서 $10.62 \%-0.40 \%$ 로 낮추었을 때, 사료섭취량에는 영향을 미치지 않았으나
일당증체량은 감소하고 사료요구율은 높았다고 본 연구의 결과와 일치하는 보고를 하였다. Karlsson 등 (1993)은 비육기 사료 내에 조단백 질 $13.1 \%$ (lysine $0.64 \%$ ) 사료 급여 시, 조단백 질 $18.9 \%$ (lysine $0.96 \%$ ) 사료 급여구에 비해 일 당증체량이 낮다고 보고하였고, Kerr 등 (1995) 도 체중 $8.6 \mathrm{~kg}$ 에서 $92.6 \mathrm{~kg}$ 까지 돼지에게 저단 백질 사료 (사육단계별로 $15 \%, 12 \%, 11 \%$ ) 급여 시, 고단백질 사료 (사육단계별로 $19 \%, 16 \%$, $14 \%)$ 급여구에 비해 일당증체량은 감소하고 사 료요구율은 높아졌다고 보고하여, 본 연구의 결과와 일치하는 경향을 보였다.

한편 CLA의 첨가유무는 일당증체량, 사료섭 취량 및 사료요구율에 영향을 미치지 않았다. 본 연구의 결과와 마찬가지로 Martin 등 (2008) 은 체중 $70 \mathrm{~kg}$ 에서 $107 \mathrm{~kg}$ 까지 CLA $0 \%, 1 \%$, $2 \%$ 를 급여하였을 때 일당증체량과 사료요구율 에 영향을 주지 않았다고 보고하였으며, 다른 연구자들의 결과에서도 CLA 급여가 돼지의 일 당증체량, 사료섭취량 및 사료요구율에 영향을 미치지 않았다(Corino 등, 2001; Ramsay 등, 2001; Gatlin 등, 2002).

Loughmiller 등 (1998)은 비육기 사료에 조단 백질 및 lysine 수준을 $10.62 \%-0.40 \%$ 에서 $14.74 \%-0.70 \%$ 로 증가시켰을 때 등지방두께가 감소된다고 보고하였고, Goerl 등 (1995)과 Kerr 등 (1995)도 사료 중 조단백질 함량을 달리하였 을 때 조단백질 수준이 높을수록 등지방두께는 감소한다고 보고하였다. 본 연구에서는 처리구 간 도체중에 차이를 보여 도체중을 공변량으로 공분산분석을 실시하여 등지방두께를 보정하였 다. 그럼에도 불구하고 본 연구에서는 $\mathrm{CLA}$ 를 $2.5 \%$ 첨가한 처리구에서는 사료 중 조단백질 수준 간 등지방두께에 차이가 없었으며, CLA 무첨가 처리구에서는 조단백질 함량이 높은 구 의 등지방두께가 오히려 두꺼웠으며 이전의 연 구 결과와 다른 양상을 보였으나, 정확한 원인 을 찾아내지는 못하였다. 사료의 조단백질 함 량이 높은 구에서 $\mathrm{CLA}$ 의 급여에 의해 등지방 두께가 감소되었는데 Sun 등 (2004)도 비슷한 결과를 보고했다. 이는 CLA의 항 지방추적작 용을 나타낸다고 볼 수 있다. 
상강도 (amrbling score) 및 등심 내 근내지방 (intramuscular fat) 함량은 조단백질 $11.3 \%$ 급여 구가 $16.0 \%$ 급여구에 비해 높았다. Kerr 등 (1995)도 체중 $8.6 \mathrm{~kg}$ 에서 $92.6 \mathrm{~kg}$ 까지 돼지에게 저단백질 사료 (사육단계별로 $15 \%, 12 \%, 11 \%$ ) 급여 시, 고단백질 사료 (사육단계별로 $19 \%$, $16 \%, 14 \%)$ 급여구에 비해 상강도가 높았다고, 본 연구의 결과와 일치하는 보고를 하였다. 또 한 많은 연구자들에 의해 저 단백질 또는 저 lysine 사료 급여 시 근내지방 함량이 증가하였 다고 보고된 바 있다 (Stahly 등, 1979; Castell 등, 1994; Essen-Gustavsson 등, 1994; Kerr 등, 1995; Cisneros 등, 1996; Blanchard 등, 1999; Witte 등, 2000; Katsumata 등, 2005; Donato 등, 2006; Park 등, 2006). 돼지의 경우 사료로 공급 되는 조단백질의 아미노산 구성 중에서 흡수된 lysine과 methionine을 이용 간과 신장에서 carnitine을 합성한 후 주로 근육에 저장하며 (Mayes 등, 1996), 지방산의 $\beta$-산화를 촉진한다. 저 단백질 사료 섭취로 인하여 불충분한 lysine 을 섭취한 돼지의 경우 carnitine 합성에 요구되 는 lysine 함량이 낮아 등심의 carnitine 함량이 저하되며, 그 결과 지방산의 $\beta$-산화는 낮아지 고 지방산의 축적이 증가하여 근내지방도나 상 강도가 높아지는 것으로 사료된다 (Katsumata 등, 2005).

반면 CLA의 첨가는 상강도나 근내지방 함량 에 영향을 미치지 않았다. 이전의 연구 결과에 서도 본 연구에서와 같이 CLA의 첨가가 등심 내 지방함량에 영향을 미치지 않았다고 보고된 바 있다 (Mueller 등, 2000; Tischendorf 등, 2002; Pastorelli 등, 2005; Martin 등, 2008). Lauridsen 등 (2005)은 체중 $40 \mathrm{~kg}$ 의 돼지를 이용하여 100 $\mathrm{kg}$ 와 $130 \mathrm{~kg}$ 출하 때까지 $\mathrm{CLA}$ 를 $0.5 \%$ 첨가한 사료 급여 시 대조구와 등심 내 지방함량에 차 이가 없었다고 보고하였고, Corino 등 (2008)도 체중 $105 \mathrm{~kg}$ 돼지를 $154 \mathrm{~kg}$ 까지 CLA $0.75 \%$ 첨 가사료 급여 시 등심 내 지방축적에 영향을 미 치지 않았다고 보고하여 본 연구의 결과와 일 치하는 경향을 보였다. 그러나 Dugan 등 (1999) 은 생체중 $61 \mathrm{~kg}$ 부터 $106 \mathrm{~kg}$ 까지 CLA를 2\% 함 유한 사료를 급여 시 해바라기유를 $2 \%$ 함유한
대조구에 비해 등심 내 지방함량 (+22\%) 및 상 강도가 증가하였다고 보고하였다. 한편 Joo 등 (2002)은 도축 전 4주 동안 CLA $0 \%, 1 \%, 2.5 \%$, 및 $5 \%$ 를 함유한 사료를 급여 시, CLA $2.5 \%$ 까 지는 등심 내 지방함량에 차이를 보이지 않았 으나, CLA 5\% 급여구에서 등심 내 지방함량이 유의적으로 증가하였다고 보고하였으나, Martin 등 (2008)의 연구 결과에서는 생체중 $70 \mathrm{~kg}$ 부터 $107 \mathrm{~kg}$ 까지 CLA를 $0 \%, 1 \%$ 및 $2 \%$ 함유한 사료 를 급여 시, 등심 내 지방함량이 각각 $2.6 \%$, $3.4 \%$ 및 $2.6 \%$ 로 CLA $1 \%$ 첨가 시에는 지방함 량이 유의적으로 증가하였으나, $2 \%$ 첨가 시에 는 대조구와 차이가 없었다. 또한 Wiegand 등 (2002)은 CLA $1.25 \%$ 첨가사료를 생체중 $28 \mathrm{~kg}$ 부터 $57 \mathrm{~kg}$ 및 $86 \mathrm{~kg}$ 까지 급여 시는 등심 내 지 방함량 및 상강도가 직선적으로 증가하였으나 그 후 $115 \mathrm{~kg}$ 까지는 정점 (plateau)에 달하였다고 보고하였다. CLA의 첨가수준이나 급여기간이 근내지방 함량이나 상강도에 미치는 영향에 대 해서는 연구자에 따라 상반된 연구 결과를 보 여주고 있으므로, 추가적인 연구가 필요할 것 으로 사료된다.

\section{V. 요 약}

본 연구에서는 비육돈 사료내 조단백질 및 CLA 수준과 그들간의 상호작용이 성장 및 육 질특성에 미치는 효과를 구명하기 위하여 수행 하였다. 공시동물은 일령이 비슷하고 체중이 $79 \pm 1 \mathrm{~kg}$ 되는 3원교잡종 48두를 공시하였다. 처 리구는 시료 중 조단백질 함량 2수준 $(11.3 \%$, $16.0 \%)$ 과 CLA 함량 2 수준 $(0 \%, 2.5 \%)$ 의 $2 \times 2$ 요인실험으로, 처리당 4 반복, 반복당 3 두씩 완 전임의 배치하였다.

종료체중 $(\mathrm{P}<0.05)$ 과 일당증체량 $(\mathrm{P}<0.01)$ 은 조 단백질 $11.3 \%$ 급여구가 $16.0 \%$ 급여구에 비해 유의적으로 낮았으며, 사료요구율 (feed/gain, $\mathrm{P}<$ 0.01 )은 조단백질 $11.3 \%$ 급여구가 $16.0 \%$ 급여 구에 비해 유의적으로 높았다. 도체중량은 조 단백질 $11.3 \%$ 급여구가 $16.0 \%$ 급여구에 비해 $(\mathrm{P}<0.001), \mathrm{CLA} 2.5 \%$ 첨가구가 $\mathrm{CLA}$ 무첨가구 에 비해 $(\mathrm{P}<0.01)$ 유의적으로 낮았다. 조단백질 
$11.3 \%$ 첨가구에서는 CLA의 첨가가 도체중량에 영향을 미치지 않았으나, 조단백질 $16.0 \%$ 첨가 구에서는 CLA $2.5 \%$ 첨가 시 도체중량이 유의 적으로 감소하여, 조단백질과 CLA간 상호작용 이 나타났다 $(\mathrm{P}<0.01)$. 등지방두께는 조단백질 $11.3 \%$ 급여구가 $16.0 \%$ 급여구에 비해, CLA $2.5 \%$ 첨가구가 CLA 무첨가구에 비해 유의적으 로 낮았다 $(\mathrm{P}<0.05)$. 조단백질 $11.3 \%$ 첨가구에서 는 $\mathrm{CLA}$ 의 첨가가 등지방두께에 영향을 미치지 않았으나, 조단백질 $16.0 \%$ 첨가구에서는 CLA $2.5 \%$ 첨가 시 등지방두께가 유의적으로 감소하 여, 조단백질과 CLA간 상호작용이 나타났다 $(\mathrm{P}<0.001)$. 상강도 (marbling score) 및 근내지방 (intramuscular fat) 함량은 조단백질 $11.3 \%$ 수준 의 사료를 섭취한 시험구가 조단백질 $16.0 \%$ 수 준의 사료를 섭취한 시험구보다 유의적으로 높 았다 $(\mathrm{P}<0.01)$.

결론적으로 비육후기에 저 단백질 사료 급여 로 등지방은 얇으면서 기호성이 높은 고 상강 도의 돈육생산이 가능할 것으로 사료된다. 한 편 정상적인 수준의 조단백질 사료 급여 시 $\mathrm{CLA}$ 의 첨가로 등지방두께를 낮출 수 있을 것 으로 사료된다.

\section{VI. 인 용 문 헌}

1. AOAC. 1995. Official method of analysis, 15th edition. Association of Official Analytical Chemist, Washington. DC.

2. Blanchard, P. J., Ellis, M., Warkup, C. C., Hardy, B., Chadwick, J. P. and Deans, G. A. 1999. The influence of rate of lean and subcutaneous fat tissue development on pork eating quality. Anim. Sci. 68:477-485.

3. Brown, J. M. and McIntosh, M. K. 2003. Conjugated linoleic acid in humans: Regulation of adiposity and insulin sensitivity. J. Nutr. 133: 3041-3046.

4. Castell, A. G., Cliplef, R. L., Poste-Flyun, L. M. and Butler, G. 1994. Performance, carcass and pork characteristics of castrates and gilts self-fed diets differing in protein content and lysine: energy ratio. Can. J. Anim. Sci. 74:519-528.

5. Cisneros, F., Ellis, M., Baker, D. H., Easter, R. A. and Mekeith, F. K. 1996. The influence of short-term feeding of amino acid-deficient diets and high dietary leucine levels on the intramuscular fat content of pig muscle. Anim. Sci. 63:517-522.

6. Corino, C., Magni, S., Pastorelli, G., Rossi, R. and Mourot, J. 2001. CLA in heavy pig nutrition: influence on growth, meat quality and sensory characteristics of dry-cured ham. J. Anim. Sci. 78(Suppl. 1):195.

7. Corino, C., Musella, M., Pastorelli, G., Rossi, R., Paolone, K., Costanza, L., Manchisi, A. Maiorano, G. 2008. Influences of dietary conjugated linoleic acid (CLA) and total lysine content on growth, carcass characteristics and meat quality of heavy pigs. Meat Sci. 79:307-316.

8. Donato, J., Pedrosa, R. G., Cruzat, V. F., Pires, I. S. O. and Tirapegui, J. 2006. Effects of leucine supplementation on the body composition and protein status of rats submitted to food restriction. Nutrition 22:520-527.

9. Dugan, M., Aarhus, J. L., Jeremiah, L. E., Kramer, J. K. G. and Schaefer, A. L. 1999. The effects of feeding conjugated linoleic acid on subsequent pork quality. Can. J. Anim. Sci. 79:45-51.

10. Essen-Gustavsson, B., Karlsson, A., Lundstom, K. and Enfalt, A. C. 1994. Intramuscular fat and muscle fibre lipid contents in halothane-gene-free pigs fed high or low protein diets and its relation to meat quality. Meat Sci. 38:269-277.

11. Evans, M., Geigerman, C., Cook, J., Curtis, L., Kuebler, B. and McIntosh, M. 2000. Conjugated linoleic acid suppresses triglyceride accumulation and induces apoptosis in 3T3-L1 preadipocytes. Lipids. 35:899-910.

12. Fitch, H. B. 1996. Conjugated linoleic acid offers research promise. INFORM. 7:152-159.

13. Gatlin, L. A., See, M. T., Larick, D. K., Lin, X. and Odle, J. 2002. Conjugated linoleic acid 
combination with supplemental dietary fat alters pork fat quality. J. Nutr. 132:3105-3112.

14. Goerl, K. F., Eilert, S. J., Mandigo, R. W., Chen, H. Y. and Miller, P. S. 1995. Pork characteristics as affected by two populations of swine and six crude protein levels. J. Anim. Sci. 73:3621-3626.

15. Ha, Y. L., Park, G. B., Kang, S. J., Shim, K. H. and Kim, J. O. 1998. Newly recongnized multifunctional fatty acids for the production of high quality meat, fish and agricultural products. Ministry of Agriculture and Forestry (Report):1314.

16. Ha., Y. L., Storkson, J. M. and Pariza, M. W. 1990. Inhibitation of benzo(a)pyrene-induced mouse forestomach neoplasis by conjugated dienoic derivatives of linoleic acid. Cancer Res. 50: 1097-1101.

17. Heo, K., Odle, J., Han, I. K., Cho, W., Seo, S., van Heugten, E. and Pilkington, D. H. 2000. Dietary L-carnitine improves nitrogen utilization in growing pigs fed low energy, fat-containing diets. J. Nutr. 130:1809-1814.

18. Hodgson, R. R., Davis, G. W., Smith, G. C., Savell, J. W. and Cross, H. R. 1991. Relationships between pork loin palatability traits and physical characteristics of cooked chops. J. Anim. Sci. 69:4858-4865.

19. Joo, S. T., Lee, J. I., Ha, Y. L. and Park, G. B. 2002. Effects of dietary conjugated linoleic acid on fatty acid composition, lipid oxidation, color, and water-holding capacity of pork loin. J. Anim. Sci. 80:108-112.

20. Karlsson, A., Enfalt, A. C., Essen-Gustavsson, B., Lundstrom, K., Rydhmer, L. and Stern, S. 1993. Muscle histochemical and biochemical properties in relation to meat quality during selection for increased lean tissue growth rate in pigs. J. Anim. Sci. 71:930-938.

21. Katsumata, M., Kobayashi, S., Matsumoto, M., Tsuneishi, E. and Kaji, Y. 2005. Reduced intake of dietary lysine promotes accumulation of intramuscular fat in the Longissimus dorsi muscles of finishing gilts. Anim. Sci. J. 76:237-244.

22. Kerr, B. J., McKeith, F. K. and Easter, R. A. 1995. Effect on performance and carcass characteristics of nursery to finisher pigs fed reduced crude protein, amino acid supplemented diets. J. Anim. Sci. 73:433-440.

23. Kim, J. H., Park, B. Y., Yoo, Y. M., Cho, S. H., Kim, Y. K., Lee, J. M., Yun, H. J. and Kim, K. N. 2002. Characterstics of carcass and meat yields of fattening pigs by production step. J. Anim. Sci. \& Technol. (Kor.). 44:793-800.

24. Lauridsen, C., Mu, H. and Henckel, P. 2005. Influence of dietary conjugated linoleic acid (CLA) and age at slaughtering on performance, slaughter- and meat quality, lipoproteins, and tissue deposition of CLA in barrows. Meat Sci. 69:393-399.

25. Loughmiller, J. A., Nelssen, J. L., Goodband, R. D., Tokach, M. D., Titgemeyer, E. C. and Kim, I. H. 1998. Influence of dietary lysine on growth performance and carcass characteristics of latefinishing gilts. J. Anim. Sci. 76:1075-1080.

26. Martin, D., Muriel, E., Gonzalez, E., Viguera, J. and Ruiz, J. 2008. Effect of dietary conjugated linoleic acid and monounsaturated fatty acids on productive, carcass and meat quality traits of pigs. Livest. Sci. (in press).

27. Mayes, P. A. 1996. Oxidation of fatty acids: ketogenesis. In: Murray, R. K., Granner, D. K., Mayes, P. A. and Rodwell, V. W.(eds), Harper's Biochemistry, 24th edition, Appleton and Lange, Stanford. pp:224-235.

28. Mueller, H. L., Kirchgessner, M., Roth, F. X. and Stangl, G. I. 2000. Effect of conjugated linoleic acid on energy metabolism in growing-finishing pigs. J. Ani. Phys. Ani. Nutrition. 83:85-94.

29. NRC. 1998. Nutrient requirement of swine, 10th edition. National Academy Press, Washington, DC.

30. Pariza, M. W., Park, Y. and Cook, M. E. 2000. Mechanisms of action of conjugated linoleic acid: Evidence and speculation. Pro. Soc. Exp. Biol. Med. 223:8-13. 
31. Park, B. Y., Yoo, Y. M., Kim, J. H., Cho, S. H., Kim, S. T., Lee, J. M. and Kim, Y. K. 1999. Effect of intramuscular fat contents on meat quality of pork loins. Kor. J. Anim. Sci. 41:59-64.

32. Park, J. C., Kim, Y. H., Jung, H. J., Lee, S. D., Cho, K. H., Kim, I. C., Lee, S. J. and Moon, H. K. 2006. Effects of Dietary L-leucine levels in low-lysine diets on growth performance and meat quality parameters in finishing duroc pigs. J. Anim. Sci. \& Technol. (Kor.). 48:813-818.

33. Park, Y., Albreight, K. J., Liu, W., Storkson, J. M., Cook, M. E. and Pariza, M. W. 1997. Effect of conjugated linoleic acid on body composition in mice. Lipids 32:853-858.

34. Pastorelli, G., Moretti, V., Macchioni, P., Lo Fiego, D., Santoro, P., Panseri, S., Rossi, R. and Corino, C. 2005. Influence of dietary conjugated linoleic acid on the fatty acid composition and volatile compounds profile of heavy pig loin. J. Sci. Food Agric. 85:2227-2234.

35. Ramsay, T. G., Evock-Clover, C. M., Steele, N. C. and Azain, M. J. 2001. Dietary conjugated linoleic acid alters fatty acid composition of pig skeletal muscle and fat. J. Anim. Sci. 79:21522161.

36. SAS. 1998. Applied statistics and the SAS programming language. SAS Institute INC, Cary, NC, USA.
37. Stahly, T. S., Cromwell, G. L. and Aviotti, M. P. 1979. The effect of environmental temperature and dietary lysine source and level on the performance and carcass characteristics of growing swine. J. Anim. Sci. 49:1242-1251.

38. Sun, D., Zhu, X., Qiao, S. and Li, D. 2004. Effects of conjugated linoleic acid levels and feeding intervals on performance, carcass traits and fatty acid composition of finishing barrows. Arch. Anim. Nutr. 58:277-286.

39. Tischendorf, F., Shone, F., Kircheim, U. and Jahreis, G. 2002. Influence of a conjugated linoleic acid mixture on growth, organ weights, carcass traits and meat quality in growing pigs. J. Anim. Physiol. Anim. Nutr. 86:117-128.

40. Wiegand, B. R., Sparks, J. C., Parrish, Jr. F. C. and Zimmerman, D. R. 2002. Duration of feeding conjugated linoleic acid influences growth performances, carcass traits and meat quality of finishing barrows. J. Anim. Sci. 80:637-643.

41. Witte, D. P., Ellis, M., McKeith, F. K. and Wilson, E. R. 2000. Effect of dietary lysine level and environmental temperature during the finishing phase on the intramuscular fat content of pork. J. Anim. Sci. 78:1272-1276.

(접수일자 : 2008. 6. 5. / 수정일자 : 2008. 8. 18. / 채택일자 : 2008. 10. 8.) 